\title{
Energy Performance Gap Analysis in Energy Efficient Residential Buildings in Lithuania
}

\author{
Violeta MOTUZIENE ${ }^{1 *}$, Vilūnė LAPINSKIENE² ${ }^{2}$, Genrika RYNKUN ${ }^{3}$, Jonas BIELSKUS ${ }^{4}$ \\ ${ }^{1-4}$ Vilnius Gediminas Technical University, Sauletekio av. 11, Vilnius, Lithuania
}

\begin{abstract}
Implementing provisions of the EPBD all Member States require to provide EPC (Energy Performance Certificate) when buildings are constructed, sold or rented. The purpose of the certificate is to compare buildings' performance and inform the end-users. However, quite many mismatches and discrepancies could be found when comparing actual energy consumption with the once declared by the EPC. This mismatch of energy demand is known as Energy Performance Gap (EPG). It was analysed by different researchers on national levels. In the study, an overall overview of the high-performance buildings in Lithuania is performed and EPG is analysed using statistical indicators. Analysis has shown that for class $A$ the EPG varies from $-101 \%$ to $+77 \%$. More buildings are found to have a positive Energy Performance Gap. For class $\mathrm{A}+$ and $\mathrm{A}++$ variations are within a narrower interval: from +18 to $76 \%$ and from +23 to $77 \%$ accordingly. It confirms the findings in the other countries that very high-energy performance buildings tend to consume more than predicted. Also it is confirmed that despite differences in national certification methodologies, the same problem (just of different scale) exists and EPC schemes need revisions.
\end{abstract}

Keywords - Actual demand; EPC; predicted; statistical analysis

\section{INTRODUCTION}

The European Union (EU) is committed to developing a sustainable, competitive, secure, and decarbonized energy system by 2050 [1]. On the road of decarbonisation, buildings play an important role, causing about $36 \%$ of all $\mathrm{CO}_{2}$ emissions in EU [2]. Therefore, increased energy efficiency in the building stock is pivotal to reduce their environmental impacts. Special attention must be paid to the residential buildings as according to EU Buildings Datamapper [3], residential buildings in different countries constitute $59-89 \%$ of the building stock and they are one the main energy consumers.

Implementing provisions of the EPBD (Directive 2010/31/EU) [4], all Member States require to provide EPC (Energy Performance Certificate) when buildings are constructed, sold or rented. Therefore, EPC's became one of the widest and foremost data sources on the energy performance of the European buildings [5], [6]. In addition, it is expected to reduce energy consumption and carbon emissions by providing market actors with information to make better-informed decisions [7]. However, quite many mismatches and discrepancies could be found [6], [8] when comparing actual energy consumption with the EPC data. This mismatch is known as Energy Performance Gap (EPG) [9], [10].

Recently various studies have been published demonstrating EPG when actual energy consumption is compared to EPCs data. Most of them are based on statistical analysis of national databases, e. g., [11] has examined the EPG of 34816 Swiss residential buildings;

* Corresponding author.

E-mail address: violeta.motuziene@vilniustech.lt 
[12] analysed almost 200000 EPCs data for Dutch residential buildings; [13] investigated 537 Flemish dwellings, trying to find out the accuracy of EPC prediction, when assessing the actual energy use in high-performance houses. All the above mentioned studies (also some other) came to the same conclusions that in different countries buildings with poor thermal performance consume much less energy than predicted based on EPC data (having a negative EPG) and energy efficient buildings use up more (having a positive EPG). As the result, EPG raise doubts in reliability of data when property owners take decisions about retrofit investments [14].

Some findings stress importance of assumptions used in EPC ratings and simulation models, including occupancy and space heating patterns [13], [15]. Cozza et al. [14] has noticed that the type of heating system does not influence the EPG, so the gap is caused mainly by the operation of the energy using systems and appliances rather than their technical properties. All those end uses relate to the occupants' presence schedules and their behaviour in occupied space [16]. Occupancy patterns [17] differ greatly from actual consumption because both EPC's and the simulation tools do not accurately assess the dynamics of users' presence in a building (passive behaviour) and the specifics of consumer behaviour in certain buildings or even areas [18]. These discrepancies in occupancy profiles limit the ability of energy models to accurately predict the actual efficiency of a building [19]. The solution to provide reliable information on buildings actual energy performance supposed to be certification based on the measured energy consumption, as it is done in some countries. However, even in this case, as shows study performed in Sweden, errors are not avoided, because of different reasons [5].

EPC's are being renewed in many countries so there are advanced research opportunities to examine energy performance development gradually and to assess the building-specific effect of energy policies and measures [5], [20]. It is obvious, that problem related to simplification of assumptions related to single, average user profile, as given in the majority of calculation methods, must be taken into account in renewal of the methodologies. EPC's have also the potential to be improved to track indoor air quality and the life cycle related environmental impact of the building components, thus filling the social and environmental gaps [21].

The goal of the paper is to analyse statistically the scale of the Energy Performance Gap in Lithuanian energy efficient buildings. Analysis consists of 3 stages:

1. Theoretical analysis of all energy efficient $(\mathrm{A}, \mathrm{A}+, \mathrm{A}++)$ buildings;

2. Collection, filtering and normalisation of the actual data;

3. Statistical analysis and comparison of the actual energy consumption vs EPC data in multi-family buildings.

Because of data availability and comparability limitations, just heating energy demand and for buildings with district heating as energy source are analysed in this stage.

\section{METHODOLOGY}

The analysis is separated into 3 stages (theoretical data analysis, actual data analysis and comparison of actual vs theoretical efficiency) composed of smaller steps (Fig. 1). 


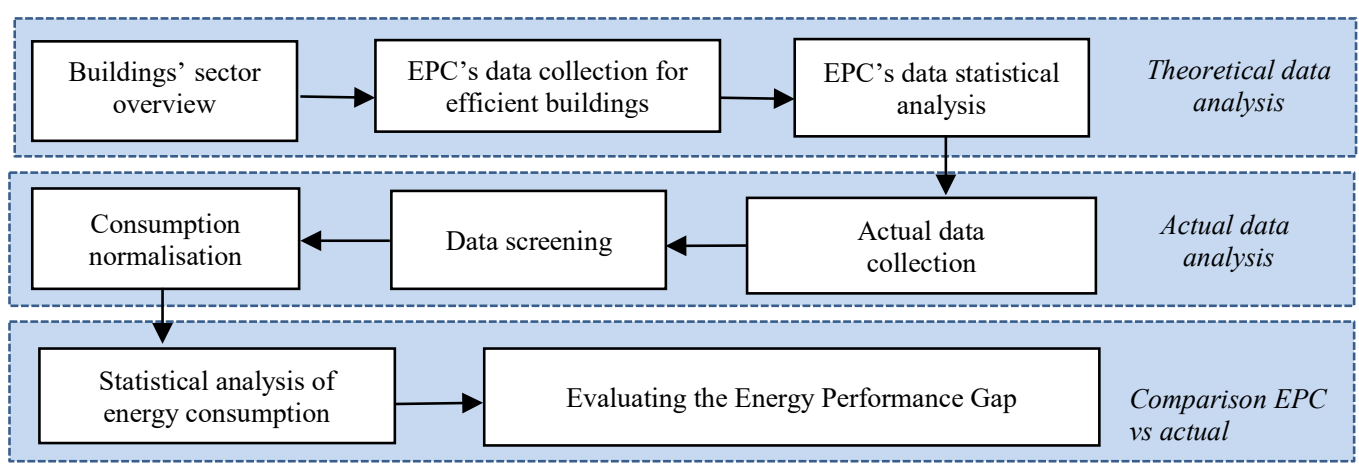

Fig. 1. Schematic representation of the methodology of the study.

\subsection{Theoretical Data Analysis}

As the first step authors made an analysis of the overall building sector situation in Lithuania and an analysis of the Energy Performance Certification situation. For this purpose, mainly data from [22] and national EPC database SPSC [23] were used.

The study mainly focuses on energy efficient buildings; therefore, inefficient buildings EPC data are excluded from the analysis. Energy efficient buildings are considered those buildings with the EPC rating $\mathrm{A}, \mathrm{A}+$ and $\mathrm{A}++$. The last one corresponds to the national definition of the Nearly Zero Energy Building and implementing provisions of the EPBD is required to build since 2021. EPC energy consumption data are calculated based on quasi-steady-state monthly method.

Theoretical statistical analysis is limited to thermal energy demand for heating, as because of different certification methodologies, just this number is available for all energy efficiency classes. Buildings of different purposes and 3 classes are analysed using statistical indicators.

\subsection{Actual Data Analysis}

To create a reliable dataset with matched and comparable EPCs, data were collected, filtered and normalised. Actual data were collected from district heating companies just for multi-family residential buildings, because data on public and commercial buildings' actual energy consumption are not publicly available and cannot be used without the permissions of the building's owners. Also, because energy demand for heating in national EPC methodology is influenced by the type of the heating source. Therefore, just buildings with DH systems can be compared.

The number of data from DH companies for the full year was gathered for more than 100 buildings, but after the manual screening, it was noticed that some newly built buildings obviously were not yet fully occupied, data for some months were missing or heating energy consumption was not separated from consumption for DHW. Therefore, finally sample size decrease to 64 buildings.

For the selected buildings energy data normalisation was performed to eliminate influence of the external temperatures on the consumption. Normalisation was performed on a monthly basis, using actual average monthly external temperatures for the analysed periods, using Eq. (1) [24]. 


$$
Q_{a . h . n}=Q_{a . h} \cdot \frac{\left(\theta_{i . n}-\theta_{e . n}\right) \cdot z_{n}}{\left(\theta_{i . n}-\theta_{e . n}\right) \cdot z_{a}}
$$

where

$Q_{a . h . n}$ Normalized actual heating energy consumption for the analysed period, MWh;

$Q_{a . h} \quad$ Actual heating energy consumption for the analysed period, MWh;

$\theta_{i . n} \quad$ Standard indoor air temperature, ${ }^{\circ} \mathrm{C}$;

$z_{n} \quad$ Standard duration of the analysed period, in days;

$\theta_{e . n} \quad$ Average outdoor air temperature for the analysed period, ${ }^{\circ} \mathrm{C}$;

$\theta_{i . a} \quad$ Actual indoor air temperature, which was assumed to be $0.21{ }^{\circ} \mathrm{C}$ based on previous research [25], as it could not be measured in such a number of buildings, ${ }^{\circ} \mathrm{C}$;

$\theta_{\text {e.a }} \quad$ Average actual outdoor air temperature for the analysed period, ${ }^{\circ} \mathrm{C}$;

$z_{a} \quad$ Duration of the analysed period, in days.

\subsection{Comparison of EPC vs Actual Consumption}

This is the final stage of the analysis, when using Excel descriptive statistics, the graphical comparison with main statistical indicators, such as R-squared, mean, medium, minimum, maximum and etc. was performed.

According to Lithuanian EPC regulation [26], buildings final energy performance is assessed based on the overall primary energy consumption, but there are intermediate indicators that must be satisfied, to receive a certain energy efficiency class. One them is the above analysed is final energy demand for heating. The required maximum limit of the heating energy consumption is calculated based on the Eqs. (2)-(4) and depends on $k_{h}-$ correction factor, which for residential buildings equals to one and $A$ - building area, $\mathrm{m}^{2}$.

$$
\begin{aligned}
& \text { For class A: } Q_{\max }=k_{h} \cdot 265 \cdot A^{-0.24} \\
& \text { For class A+: } Q_{\max }=k_{h} \cdot 215 \cdot A^{-0.23} \\
& \text { For class } \mathrm{A}++: Q_{\max }=k_{h} \cdot 197 \cdot A^{-0.23}
\end{aligned}
$$

\section{RESUlts}

Performed general overview of the Lithuanian building stock shows that residential buildings are dominant and their share is $64 \%$ [22] (according to area). The area of residential buildings is growing the most and similar situation can be found also in other European countries [3]. Just $14 \%$ (in terms of area) of Lithuanian residential buildings have B or higher energy efficiency class and they consume $67 \%$ of thermal energy and $63 \%$ of the primary energy related to the building stock.

Overall EPC data from [23] were extracted in November of 2020 just for energy efficient $(\mathrm{A}, \mathrm{A}+$ and $\mathrm{A}++)$ buildings of all the purposes. Total amount of such buildings at that moment was 5950. As buildings of A label are required to be built from 2016, it is not surprising that they constitute the biggest share $(57 \%)$ of energy efficient buildings. A+ buildings are required to be built from 2018 and $\mathrm{A}++$ - from 2020, accordingly their share is smaller $42 \%$ and $1 \%$. It was also noticed, that $\mathrm{A}+$ buildings were already certified as $\mathrm{A}++$ before the requirements came into force. 
From the Fig. 2 it is seen that of all 5950 buildings, 5381 (90\%) are residential buildings. This is related to the above mentioned fact that building sector is dominant in the country. Energy efficient buildings of the other purposes constitute just from 1 to $3 \%$ of the area.

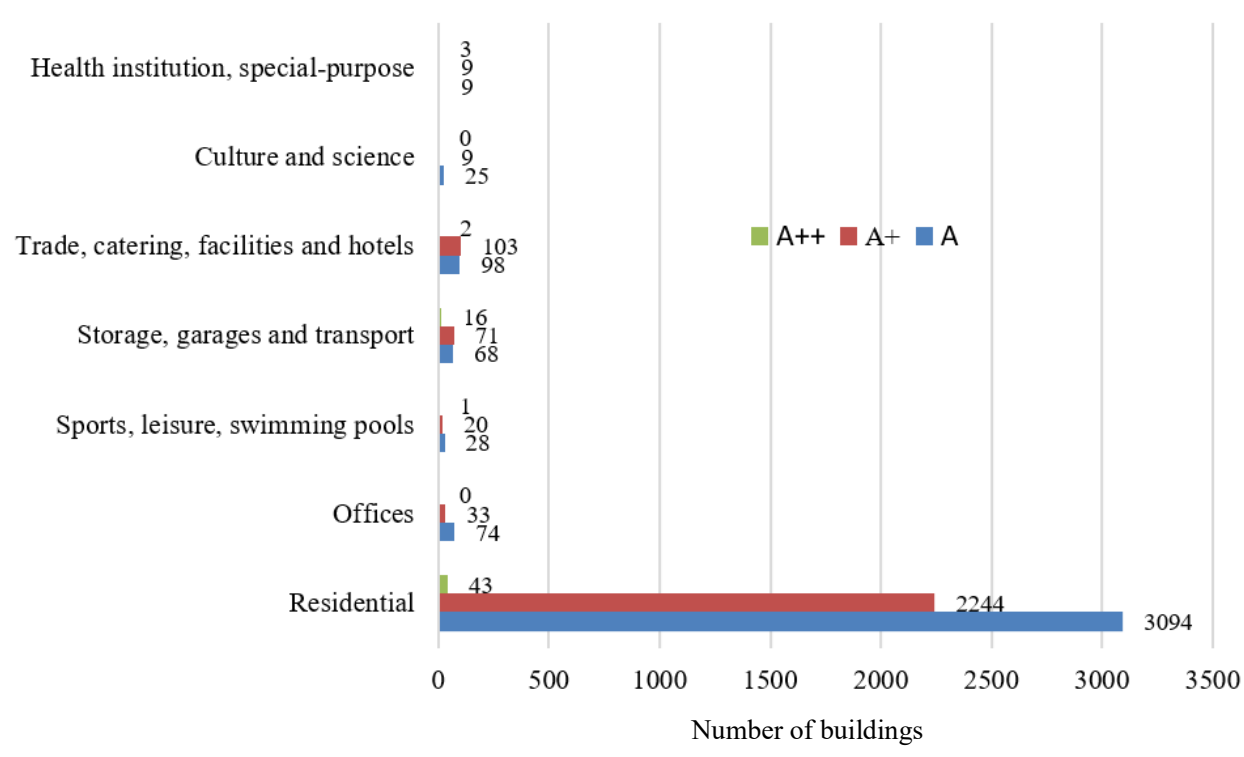

Fig. 2. Distribution of the energy efficient buildings according to the purpose.

Figs. 3-5 present the analysis of the predicted according to the EPC heating energy consumption of the buildings of different classes and purposes. For energy efficiency class A the biggest sample size is available. For higher classes it decreases because of the date when legal requirements came into force. It can be noticed from the Fig. 3 that for residential buildings variation of the predicted energy demand is abnormal and variates from 1 to $108 \mathrm{kWh} / \mathrm{m}^{2}$, with a median of $39 \mathrm{kWh} / \mathrm{m}^{2}$. Median heating energy demand for A class buildings for different purposes variates from 15 to $41 \mathrm{kWh} / \mathrm{m}^{2}$.

For the A+ buildings (Fig. 4), again, variation of predicted demand is high and very similar to the A buildings - from 1 to $91 \mathrm{kWh} / \mathrm{m}^{2}$, but the median was already just $19 \mathrm{kWh} / \mathrm{m}^{2}$, much lower compared to class A. For this class also buildings for sports, leisure and swimming pools, as well as storage, garages and transport buildings have high demand variation, even higher than for A label. Median energy consumption for this class of efficiency for different buildings variates from $13-35 \mathrm{kWh} / \mathrm{m}^{2}$, slightly less compared to class A.

For the class A++ residential buildings (Fig. 5) variation of the energy demand for heating $\left(1-29 \mathrm{kWh} / \mathrm{m}^{2}\right)$, as well as median value $\left(9 \mathrm{kWh} / \mathrm{m}^{2}\right)$ are significantly lower than for the other classes. Also significantly different results are from the buildings of the other purposes. It must be noted, that small sample sizes for this class do not allow to make reliable conclusions, e.g. for category "Sports, leisure, swimming pools" there was any certified pool, therefore energy demand value for this category is very small.

Situation, when buildings with lower energy demand have higher labels (e.g. comparing A and $\mathrm{A}++$ buildings) can be explained by the fact, that heating energy demand is just one of the intermediate requirements and if building with low predicted energy demand does not satisfy some other requirement or overall primary energy demand it gets lower energy efficiency class. 


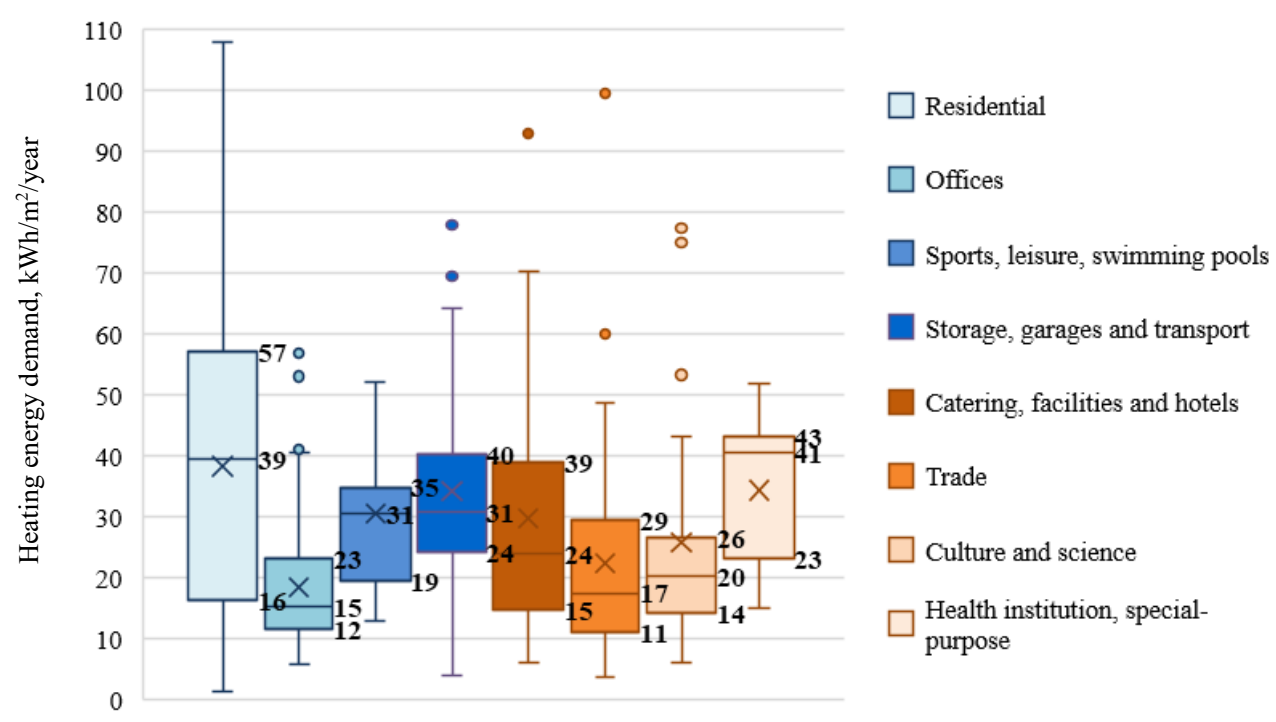

Fig. 3. Annual heating energy demand of different type class A buildings (Sample data - 3381).

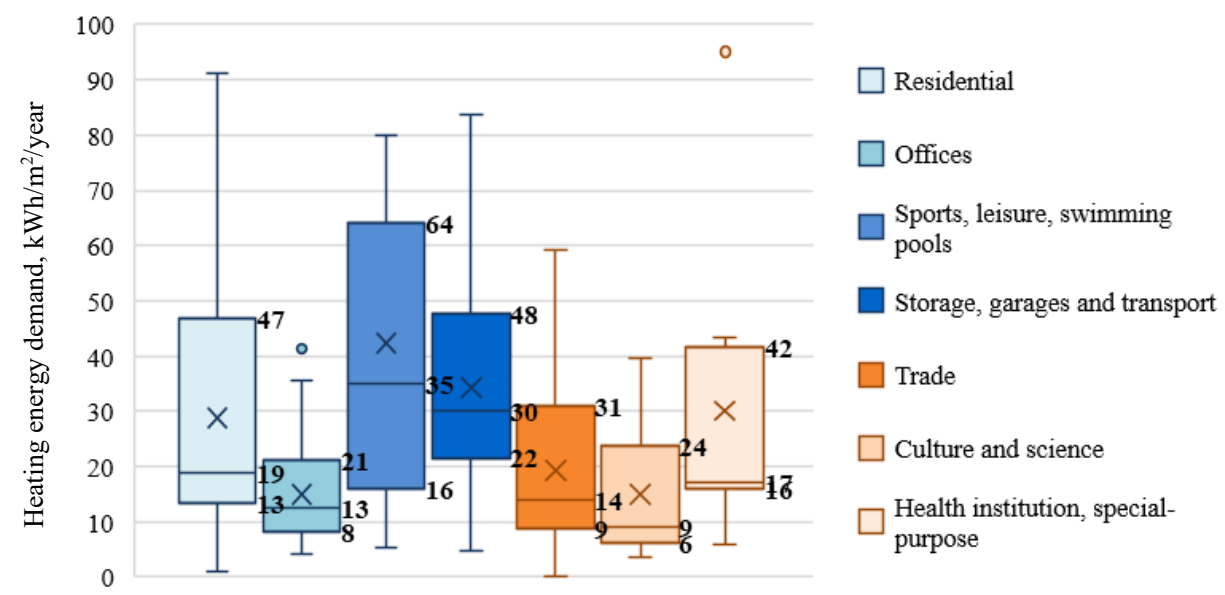

Fig. 4. Annual heating energy demand of different type class A + buildings (Sample data - 2483).

Data for actual consumption of multi-family residential buildings were collected from the district heating companies, further they went through manual screening and the selected ones were normalized according to Eq. (1) to perform a comparison with the EPC data. The results are analysed using different statistical indicators and presented in Figs. 6-8. 


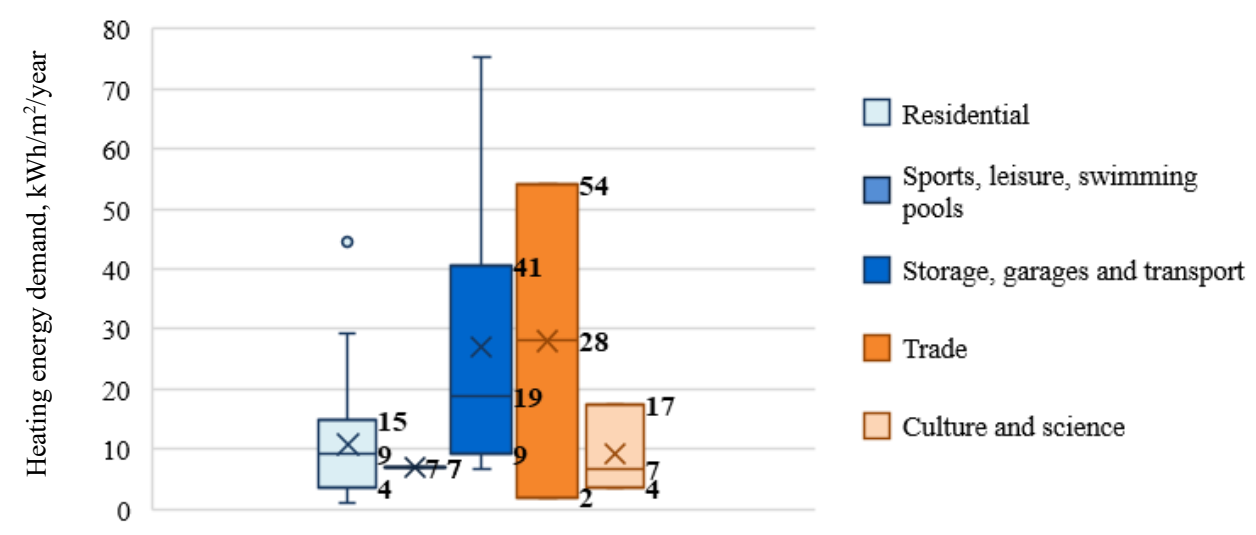

Fig. 5. Annual heating energy demand of different type class A ++ buildings (Sample data -61 ).

To measure a strength of the relationship between EPC predicted and actual energy consumption the scatterplot and regression analysis is employed (Fig. 6). The linear regression lines for every data group show that: for class A with the highest data set, there is almost no correlation between predicted and actual energy consumption for heating. Meanwhile for class A+ correlation is strong and opposite situation is for the class $\mathrm{A}++-$ week. For the class A++ number of samples is small (5), therefore this data cannot be considered as reliable regression data.

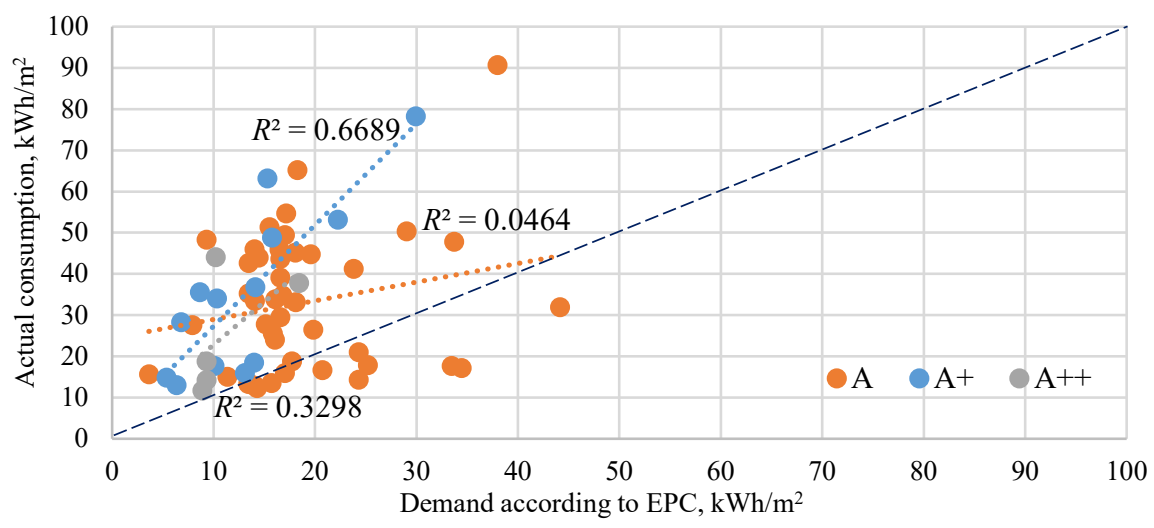

Fig. 6. Correlation between theoretical and actual energy demand.

Absence of correlation of the class A buildings' energy consumption with the EPC data can be also explained by high percentage error, which is shown in Fig. 7. For class A the variation of the percentage error is from $-101 \%$ to $+77 \%$. More buildings are found to have the positive EPG. For the more efficient buildings, e.g. for class $\mathrm{A}+$ and $\mathrm{A}++$ variations are within more narrow interval $+18-76 \%$ and $+23-77 \%$ accordingly.

The fact that negative EPG is found just for class A buildings partially confirms the findings of [14], that very high energy efficiency buildings tend to consume more than predicted and less efficient - less than predicted. It can be also assumed, that some points in the Fig. 6 also can move from the positive EPG zone to the negative EPG zone, if actual temperature in those 
buildings would be higher than that assumed in the study. This can be also considered as occupant's influence as in all new construction residential buildings users have the possibility to control the temperatures.

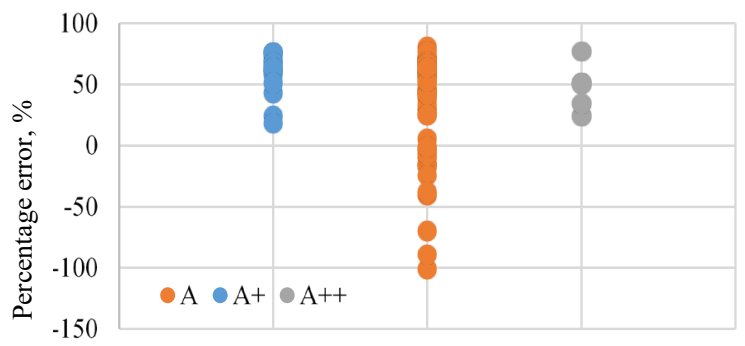

Fig. 7. Percentage error between the predicted by EPC and actual energy consumption.

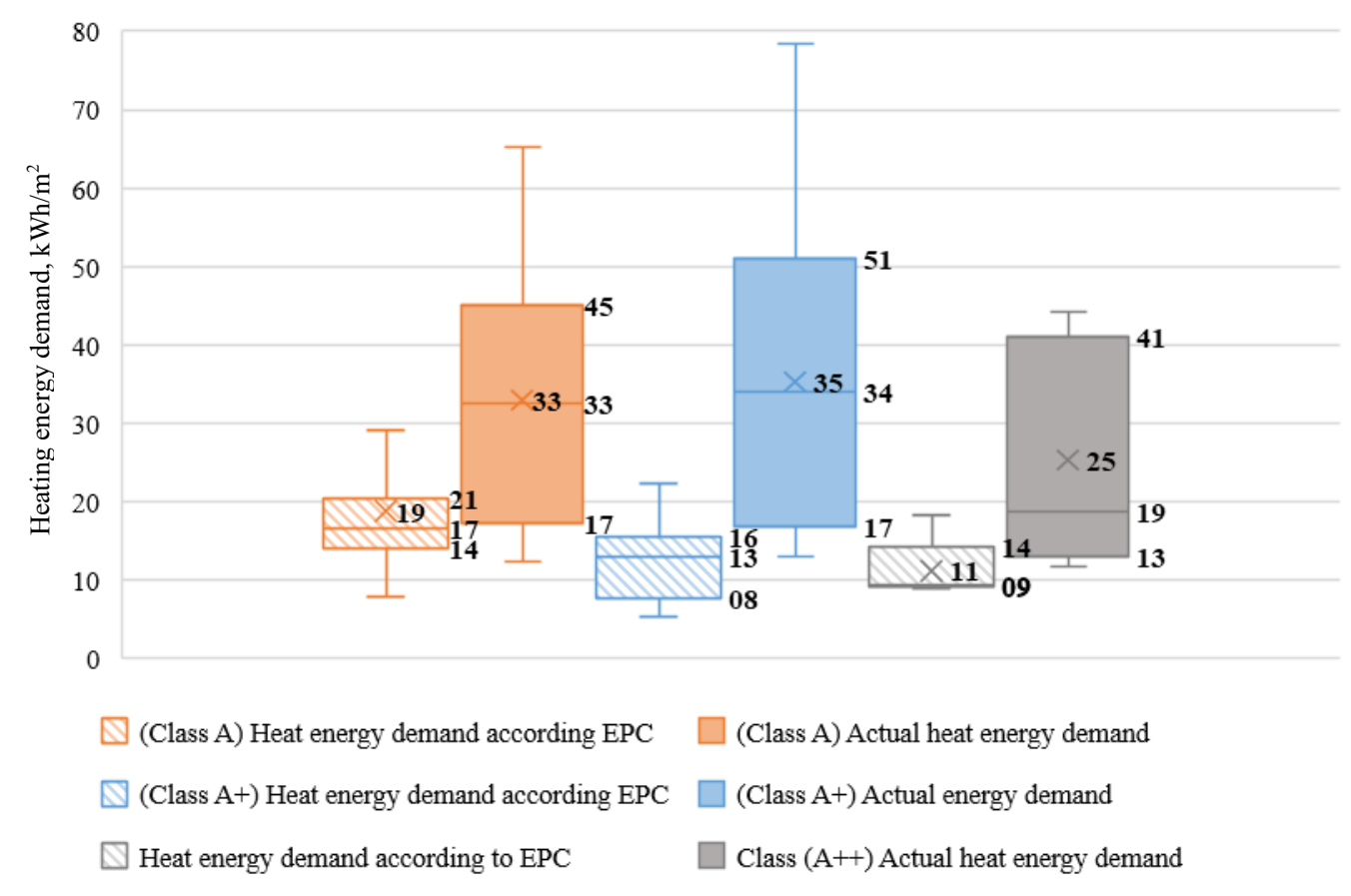

Fig. 8. Predicted and actual heating energy consumption.

Comparing actual energy consumption values for analysed multi-family residential buildings seen (Fig. 8) for all three energy performance classes, the median (and mean) values of actual energy demand are as follows: A - $33(33) \mathrm{kWh} / \mathrm{m}^{2} ; \mathrm{A}+-34(35) \mathrm{kWh} / \mathrm{m}^{2}$ and $19(25) \mathrm{kWh} / \mathrm{m}^{2}$. Interesting situation appears, that for A+ energy efficiency class buildings have slightly worse energy consumption compared to the lower A class. The maximum values in the boxes are also higher for better class. Meanwhile according to the EPC, predicted values 
by EPC decrease proportionally to higher energy performance class. It proves that reality does not correspond to the theory and certification methodology needs to be improved.

In an ideal case, all normalized actual energy demand should be smaller than predicted by EPC and maximum allowed. But the results for class A buildings show (Fig. 9(a)) that there are 10 cases, when normalized actual heating energy demand exceeds the maximum allowed energy consumption, also 12 cases, when normalized actual energy demand were smaller, than predicted by EPC. Maximum allowed heat energy demand calculated based on Eq. (2)Eq. (4) varies from 29 to $72 \mathrm{kWh} / \mathrm{m}^{2}$, while actual consumption varies dramatically from 12 to $91 \mathrm{~kW} / \mathrm{m}^{2}$. For class A+ (Fig. 9(b)) actual energy consumption varies in a wide interval from 13 to $78 \mathrm{kWh} / \mathrm{m}^{2}$ and no tendencies could be seen due to small number of the analysed buildings. Meanwhile, maximum allowed energy demand varies from $28-45 \mathrm{kWh} / \mathrm{m}^{2}$. For A++ buildings (Fig. 9(c)), where sample size is not sufficient to make some judgements, the values for actual energy demand vary from 14 to $44 \mathrm{kWh} / \mathrm{m}^{2}$ and predicted by EPC 9$18 \mathrm{kWh} / \mathrm{m}^{2}$. Common for all the classes is that in most cases EPC values are much lower than the maximum allowed, but in reality they are much higher or even exceeding them.

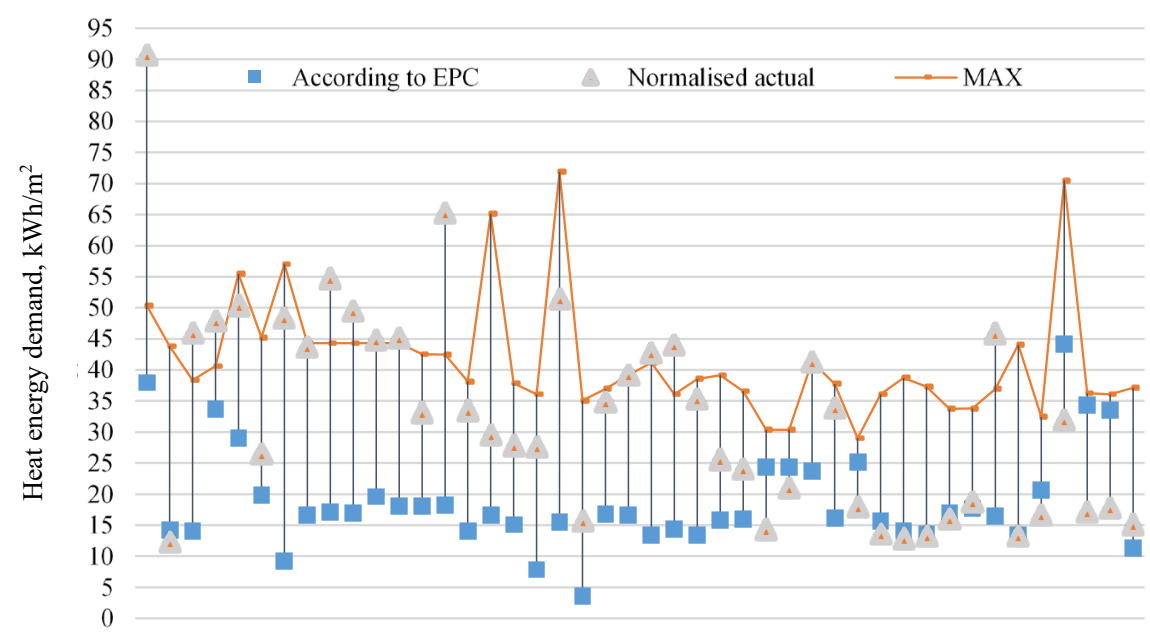

(a)

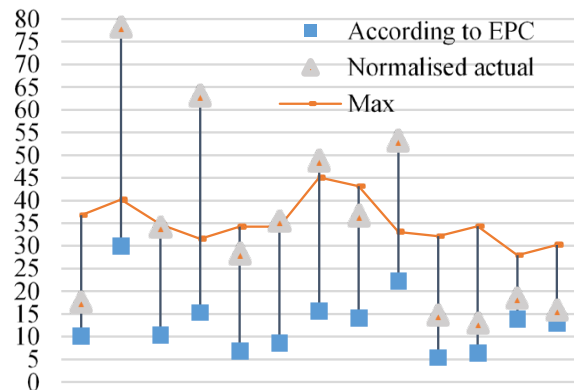

(b)

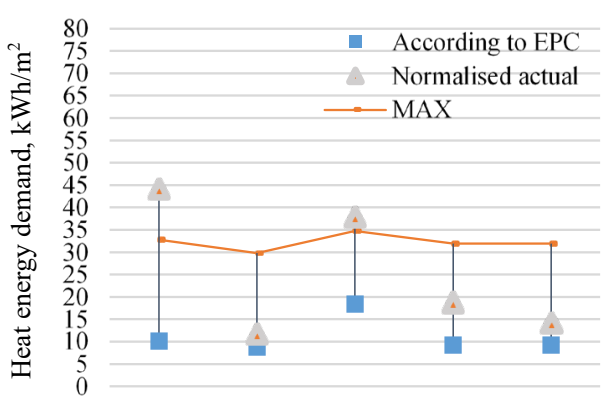

(c)

Fig. 9. Energy demand comparison to the allowed maximum: a) class A; b) class A+; b) class A++. 


\section{Conclusion}

The study has analysed EPG high-energy performance (from class A to A++) buildings. Analysis of the actual energy demand for multi-storey residential buildings has shown very high prediction errors. For class A the EPG varies from $-101 \%$ to $+77 \%$ and more buildings are found to have a positive Energy Performance Gap. For class $\mathrm{A}+$ and $\mathrm{A}++$ variations are within a narrower interval: from +18 to $76 \%$ and from +23 to $77 \%$ accordingly.

Median actual heating energy consumption in analysed residential buildings was found as follows: for class $\mathrm{A}-33 \mathrm{kWh} / \mathrm{m}^{2}$; for class $\mathrm{A}+-34 \mathrm{kWh} / \mathrm{m}^{2}$ and for class $\mathrm{A}++-19 \mathrm{kWh} / \mathrm{m}^{2}$.

Comparing actual and EPC heating energy demand, strong correlation was found just for class A+ buildings. Meanwhile for class A no correlation was found.

Different scale of EPG on national level found by the other researchers cannot be directly compared with the results of this study, as each Member State have similar, but different EPC methodologies, authors compare different indicators (heating, electricity or primary energy) and different energy efficiency buildings. However, from the results of this study it can be also confirmed that energy performance of the less efficient buildings tends to have negative gap, as found by [14]. The negative EPG is a big problem in estimation of real savings and in retrofit projects, as savings are overestimated. But the positive EPG is also a problem for new high-performance buildings, as investors and/or owners are disappointed as they do not get expected results for their additional investments. It is obvious, that in Lithuania and other countries national methodologies need to be improved to avoid or to decrease to minimum the prediction errors. As it was discussed in the introduction, many studies show that realistic assumptions in EPC methodologies related to occupancy behaviour are required and can be the important reason for such gaps. As for now, in Lithuanian methodology occupancy is estimated in the simplest possible way - just as occupancy hours per day according to the building purpose. Therefore, authors' future research is related to the integration of better occupancy information into the national certification methodology to decrease the EPG.

There are two main limitations of the study:

1. A+ buildings officially are required to be built just from 2021 , therefore the sample size of the buildings with that label and also with at least one-year operational data was very limited and cannot be considered as reliable and can reflect just general tendencies. Meanwhile samples for $\mathrm{A}$ and $\mathrm{A}+$ buildings are sufficient to make some overall conclusions.

2. It was not possible to perform actual internal temperature measurements of such an amount of buildings, therefore this temperature was assumed based on previous study. Higher actual temperatures would decrease the EPG.

\section{ACKNOWLEDGEMENT}

This research was funded by a grant (No. S-MIP-20-62) from the Research Council of Lithuania (LMTLT). Authors would also like to show their gratitude to The Lithuanian District Heating Association (LDHA) for the help in collecting data from district heating companies.

\section{REFERENCES}

[1] European Commission. Communication from the Commission to the European Parliament, the Council, the European Economic and Social Committee and the Committee of the Regions. Energy Roadmap 2050. Brussels: European Commission, 2011.

[2] European Commission. Final Report of the High-Level Panel of the European Decarbonisation Pathways Initiative. Publications Office of the European Union, 2018. 
[3] European Commision: EU Buildings Datamapper [Online]. [Accessed 13.03.2021]. Available: https://ec.europa.eu/energy/eu-buildings-datamapper_lt

[4] Directive 2010/31/Eu Of The European Parliament And Of The Council of 19 May 2010 on the energy performance of buildings (recast). Official Journal of the European Union, 2010:L 153/13.

[5] Von Platten J., et al. The renewing of Energy Performance Certificates - Reaching comparability between decadeapart energy records. Applied Energy 2019:255:113902. https://doi.org/10.1016/j.apenergy.2019.113902

[6] Ahern C., Norton B. Energy Performance Certification: Misassessment due to assuming default heat losses. Energy and Buildings 2020:224:110229. https://doi.org/10.1016/j.enbuild.2020.110229

[7] Khazal A., Sønstebø O. J. Valuation of energy performance certificates in the rental market - Professionals vs. non professionals. Energy Policy 2020:147:111830. https://doi.org/10.1016/i.enpol.2020.111830

[8] Brøgger M., Wittchen K. B. Energy Performance Certificate Classifications Across Shifting Frameworks. Procedia Engineering 2016:161:845-849. https://doi.org/10.1016/j.proeng.2016.08.727

[9] Yan D., Hong T. EBC Annex 66 Final Report - Definition and simulation of occupant behavior in buildings [Online]. [Accessed 10.03.2021]. Available: https://www.iea-ebc.org/projects/project?AnnexID $=66$

[10] Delzendeh E., et al. The impact of occupants' behaviours on building energy analysis: A research review. Renewable and Sustainable Energy Reviews 2017:80:1061-1071. https://doi.org/10.1016/j.rser.2017.05.264

[11] Cozza S., Chambers J., Patel M. K. Measuring the thermal energy performance gap of labelled residential buildings in Switzerland. Energy Policy 2020:137:111085. https://doi.org/10.1016/j.enpol.2019.111085

[12] Majcen D., Itard L., Visscher H. Actual and theoretical gas consumption in Dutch dwellings: What causes the differences? Energy Policy 2013:61:460-471. https://doi.org/10.1016/j.enpol.2013.06.018

[13] Delghust M., et al. Regulatory energy calculations versus real energy use in high-performance houses. Building Research \& Information 2015:43(6):675-690. https://doi.org/10.1080/09613218.2015.1033874

[14] Cozza S., et al. Do energy performance certificates allow reliable predictions of actual energy consumption and savings? Learning from the Swiss national database. Energy and Buildings 2020:224:110235. https://doi.org/10.1016/j.enbuild.2020.110235

[15] Summerfield A. J., et al. What do empirical findings reveal about modelled energy demand and energy ratings? Comparisons of gas consumption across the English residential sector. Energy Policy 2019:129:997-1007. https://doi.org/10.1016/j.enpol.2019.02.033

[16] Ahmed K., et al. Occupancy schedules for energy simulation in new prEN16798-1 and ISO/FDIS 17772-1 standards. Sustainable Cities and Society 2017:35:134-144. https://doi.org/10.1016/j.scs.2017.07.010

[17] Hong T., et al. Ten questions concerning occupant behavior in buildings: The big picture. Building and Environment 2017:114:518-530. https://doi.org/10.1016/j.buildenv.2016.12.006

[18] Menezes A. C., et al. Predicted vs. actual energy performance of non-domestic buildings: Using post-occupancy evaluation data to reduce the performance gap. Applied Energy 2012:97:355-364. https://doi.org/10.1016/j.apenergy.2011.11.075

[19] Clevenger C. M., Haymaker J. The impact of the building occupant on energy modelling simulations. Proceedings of the Joint International Conference on Computing and Decision Making in Civil and Building Engineering 2006:36373646.

[20] Li Y., et al. Review of building energy performance certification schemes towards future improvement. Renewable and Sustainable Energy Reviews 2019:113:109244. https://doi.org/10.1016/j.rser.2019.109244

[21] dos Reis A. S., Dias M. F. Cost-optimal levels and energy performance certificates: Filling the gaps. Energy Reports 2020:6(8):358-363. https://doi.org/10.1016/j.egyr.2020.11.172

[22] Lietuvos ilgalaikè renovacijos strategija (Lithuanian long-term renovation strategy) [Online]. [Accessed 02.03.2021]. Available: https://epilietis.lrv.lt/uploads/epilietis/documents/images/Lietuvos\%20ilgalaik\%C4\%97\%20pastat\%C5\%B3\%20reno vacijos\%20strategija.pdf (in Lithuanian)

[23] Construction Products Certification Center (SPSC) [Online]. [Accessed 02.01.2021]. Available: https://www.spsc.lt/cms/

[24] Methodology for conducting comprehensive audits of energy, energy resources and cold water consumption in public buildings (in Lithuanian: Išsamiojo energijos, energijos išteklių ir šalto vandens vartojimo audito atlikimo viešojo naudojimo paskirties pastatuose metodiką) [Online]. [Accessed 02.02.2021]. Available: https://eseimas.Irs.lt/portal/legalAct/lt/TAD/TAIS.319975?jfwid=riv

[25] Ankènas V., Motuzienè V. Daugiabučių pastatų mikroklimato parametrų tyrimas (A Study of microclimate parameters in the apartment buildings). Proceedings of the 18 th Conference for Junior Researchers "Science - Future of Lithuania” 2015:5-10.

[26] Statybos techninis reglamentas STR 2.01.02:2016 "Pastatų energinio naudingumo projektavimas ir sertifikavimas". (Lithuanian Building Technical Regulation STR 2.01.02:2016 Energy Performance of Buildings: Design and

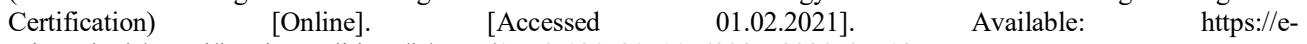
seimas.lrs.lt/portal/legalActEditions/lt/TAD/15767120a80711e68987e8320e9a5185 